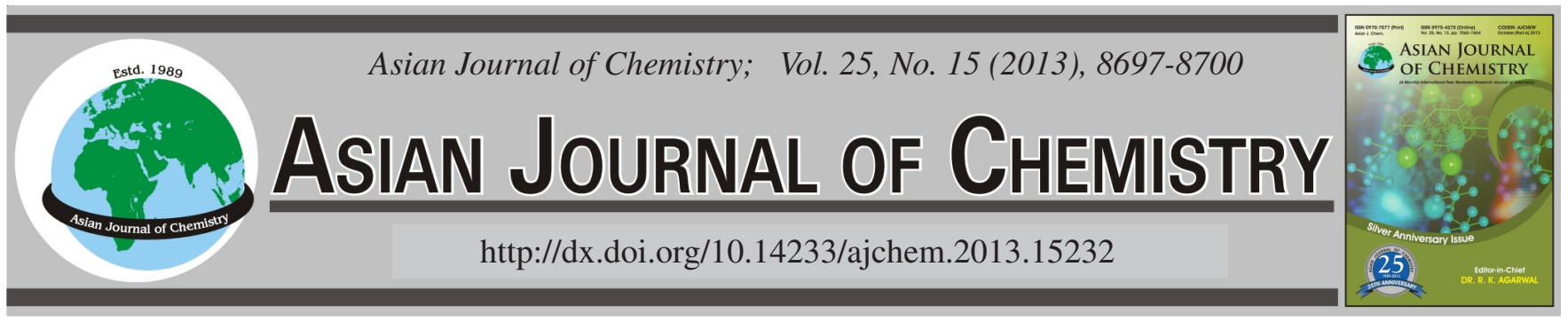

\title{
Synthesis and Crystal Structure of O-Methyldithiophosphato Nickel Complex $\left[\mathrm{Ni}\left(\mathrm{S}_{2} \mathrm{P}\{\mathrm{O}\} \mathrm{OCH} \mathrm{H}_{3}\right)(\mathrm{dppe})\right]$
}

\author{
Yu-Long Li ${ }^{1,2, *}$, BIN XIE ${ }^{2}$, Li-Ke Zou ${ }^{1}$ and XIAO LiN ${ }^{2}$
}

${ }^{1}$ Key Laboratory of Green Catalysis of Higher Education Institutes of Sichuan, Sichuan University of Science \& Engineering, Zigong 643000, P.R. China

${ }^{2}$ Institute of Functional Materials, Sichuan University of Science \& Engineering, Zigong 643000, P.R. China

*Corresponding author: Fax: +86 813 5505606; Tel: +86 813 5505601; E-mail: yu_longli@yahoo.cn

O-Methyldithiophosphato nickel complex $\left[\mathrm{Ni}\left(\mathrm{S}_{2} \mathrm{P}\{\mathrm{O}\} \mathrm{OCH} \mathrm{CH}_{3}\right)(\mathrm{dppe})\right](\mathrm{I})\left(\mathrm{dppe}=\mathrm{Ph}_{2} \mathrm{PCH}_{2} \mathrm{CH}_{2} \mathrm{PPh}_{2}\right)$ has been synthesized by treatment of (dppe) $\mathrm{NiCl}_{2}$ with $\left(\mathrm{CH}_{3} \mathrm{O}\right)_{2} \mathrm{P}\{\mathrm{S}\} \mathrm{SH} \cdot \mathrm{Et}_{2} \mathrm{NH}$ in THF solution. The new complex (I) was fully characterized by elemental analysis, TGA, IR, ${ }^{1} \mathrm{H},{ }^{13} \mathrm{C},{ }^{31} \mathrm{P}$ NMR spectroscopies. In addition the molecular structure of the complex was established by $\mathrm{X}$-ray crystallography. The crystal of $\left[\mathrm{Ni}\left(\mathrm{S}_{2} \mathrm{P}\{\mathrm{O}\} \mathrm{OCH}_{3}\right)(\mathrm{dppe})\right]$ crystallizes in monoclinic, spacegroup P21/n with a $=9.2762(3), \mathrm{b}=17.1214(5), \mathrm{c}=18.8627(6) \AA, \alpha=$ $90.00, \beta=96.813(3), \gamma=90.00^{\circ}, \mathrm{V}=2974.66(15) \AA^{3}, \mathrm{Z}=4, \mathrm{C}_{27} \mathrm{H}_{27} \mathrm{O}_{2} \mathrm{P}_{3} \mathrm{~S}_{2} \mathrm{Ni}, \mathrm{Mr}=599.23, \mathrm{D}_{\mathrm{c}}=1.338 \mathrm{~g} / \mathrm{cm}^{3}, \mathrm{~F}(000)=1240$ and $\mu\left(\mathrm{MoK}_{\alpha}\right)$ $=0.976 \mathrm{~mm}^{-1}$. The final $\mathrm{R}=0.0521$ and $\mathrm{wR}=0.1303$ for 6073 observed reflections $[\mathrm{I}>2 \sigma(\mathrm{I})]$.

Key Words: $\mathrm{Ph}_{2} \mathrm{PCH}_{2} \mathrm{CH}_{2} \mathrm{PPh}_{2}$, Dithiophosphate, Synthesis, X-ray crystallography.

\section{INTRODUCTION}

The nickel complexes (diphosphine) $\mathrm{NiCl}_{2}$ (diphosphine $=$ dppe, dppv, dppf) have been received special attention, largely because of their unique structure and their use in Suzuki-type coupling of boronic acids ${ }^{1-5}$. The main advantage of nickel in this application is that it reacts more readily with aryl chlorides and methane sulfonates than does the Pd system. In recent years, the nickel complexes (diphosphine) $\mathrm{NiCl}_{2}$ have also been used to synthesize [NiFe] hydrogenases models. A series of $[\mathrm{NiFe}]$ hydrogenases models (dppe) $\mathrm{Ni}(\mu-\mathrm{S})_{2} \mathrm{Fe}_{2}(\mathrm{CO})_{6}$ and (dppf) Ni $(\mu-\mathrm{S})_{2} \mathrm{Fe}_{2}(\mathrm{CO})_{6}$ have been synthesized by treatment of $(\mu-\mathrm{SLi})_{2} \mathrm{Fe}_{2}(\mathrm{CO})_{6}$ with (dppe) $\mathrm{NiCl}_{2}$ and (dppf) $\mathrm{NiCl}_{2}$, respectively ${ }^{6-10}$. Especially, Schmidt prepared an important complex (dppe)Ni(pdt) by reaction of (dppe) $\mathrm{NiCl}_{2}$ with $\mathrm{HSCH}_{2} \mathrm{CH}_{2} \mathrm{CH}_{2} \mathrm{SH}^{11,12}$, which has been used to synthesized [NiFe] hydrogenases model complex (dppe) $\mathrm{Ni}\left(\mu\right.$-pdt)Fe(CO) ${ }_{3}{ }^{13}$, that attracted our interest.

In view of the above information and as a continuation of our studies on such complexes, we herein report the synthesis and crystal structure of O-methyldithiophosphato nickel complex $\left[\mathrm{Ni}\left(\mathrm{S}_{2} \mathrm{P}\{\mathrm{O}\} \mathrm{OCH}_{3}\right)(\mathrm{dppe})\right](\mathbf{I})$, we expect it can be used to synthesis the $[\mathrm{NiFe}]$ hydrogenases models.

\section{EXPERIMENTAL}

All solvents were dried using standard procedures and distillated under $\mathrm{N}_{2}$. $\mathrm{Ni}$ (dppe) $\mathrm{Cl}_{2}$ was prepared according to<smiles>COP1(=O)S[N+]2(S1)P(c1ccccc1)CCP2(c1ccccc1)(c1ccccc1)c1ccccc1</smiles>

(I)

Structure of the title complex (I)

literature procedures ${ }^{14}$. Some other materials were available commercially. Melting points were determined on a SGW X4 microscopic melting point apparatus and were uncorrected. Elemental analyses for carbon, hydrogen were performed on a Perkin-Elmer 240C analyzer. IR spectra were recorded at room temperature on a Bruker Vector 22 infrared spectrophotometer. ${ }^{1} \mathrm{H},{ }^{13} \mathrm{C},{ }^{31} \mathrm{P}$ NMR spectra were obtained on a Varian Mercury Plus 400 NMR spectrometer. TGA measurement was carried out on a NETZSCH STA 409 PC/PG instrument.

Synthetic procedure: $\left(\mathrm{CH}_{3} \mathrm{O}\right)_{2} \mathrm{P}\{\mathrm{S}\} \mathrm{SH} \cdot \mathrm{Et}_{2} \mathrm{NH}(0.227 \mathrm{~g}$, $1.0 \mathrm{mmol}), \mathrm{Ni}(\mathrm{dppe}) \mathrm{Cl}_{2}(0.264 \mathrm{~g}, 0.5 \mathrm{mmol})$ and THF (15 $\mathrm{mL}$ ) are added to a 3 -neck round bottomed flask. The mixture was stirred at room temperature for $1 \mathrm{~h}$. Then volatiles were 
removed under vacuum and the residue was subjected to TLC using $\mathrm{CH}_{2} \mathrm{Cl}_{2} / \mathrm{MeOH}(\mathrm{v} / \mathrm{v}=5: 1)$ as eluent. From the main red band, the title complex (I) $(0.255 \mathrm{~g}, 85 \%)$ was obtained as an orange solid. m.p. $200-202{ }^{\circ} \mathrm{C}$. Anal. calcd. (\%) for $\mathrm{C}_{27} \mathrm{H}_{27} \mathrm{NiO}_{2} \mathrm{P}_{3} \mathrm{~S}_{2}$ : C, 54.12, H, 4.54; Found (\%): C, 54.01, H, 4.83. IR $\left(\mathrm{KBr}, \mathrm{v}_{\max }, \mathrm{cm}^{-1}\right)$ : 3052, 2986, 1607, 1503, 1435, 1203, 1161, 1100, 998, 889, 691, 557. ${ }^{1} \mathrm{H}$ NMR (400 MHz, DMSO,

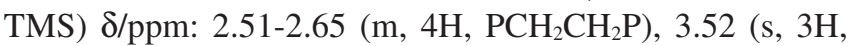
$\left.\mathrm{CH}_{3}\right)$, 7.54-7.80 (m, 20H, 4C $\left.\mathrm{C}_{6} \mathrm{H}_{5}\right) .{ }^{13} \mathrm{C} \mathrm{NMR}(100.6 \mathrm{MHz}$, DMSO): $26.72\left(\mathrm{PCH}_{2} \mathrm{CH}_{2} \mathrm{P}\right), 53.48\left(\mathrm{OCH}_{3}\right), 115.50,127.57$, 129.55, 130.16, 132.20, 133.00, $133.39\left(\mathrm{C}_{6} \mathrm{H}_{5}\right) \mathrm{ppm} .{ }^{31} \mathrm{P} \mathrm{NMR}$

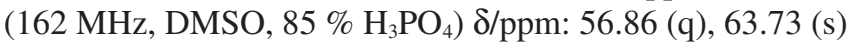
ppm.

Crystal structure determination: Single crystal of the title complex (I) suitable for X-ray diffraction analysis was grown by slow evaporation of the $\mathrm{CH}_{2} \mathrm{Cl}_{2}$ /hexane solution at $-5^{\circ} \mathrm{C}$. The crystal of (I) with dimensions of $0.40 \mathrm{~mm} \times 0.36$ $\mathrm{mm} \times 0.24 \mathrm{~mm}$ was mounted on a Rigaku RAXIS-RAPID diffractometer equipped with a graphite-monochromated $\operatorname{MoK}_{\alpha}$ radiation $(\lambda=0.71073 \AA$ ) by using an $\omega$ scan mode at $143(10) \mathrm{K}$ in the range of $3.25^{\circ} \leq \theta \leq 26.37^{\circ}$. The crystal belongs to monoclinic system with space group P21/n and crystal parameters of $\mathrm{a}=9.2762(3) \AA, \mathrm{b}=17.1214(5) \AA, \mathrm{c}=$ $18.8627(6) \AA, \alpha=90.00^{\circ}, \beta=96.813(3)^{\circ}, \gamma=90.00^{\circ}, \mathrm{V}=$ $2974.66(15) \AA, D_{c}=1.338 \mathrm{~g} / \mathrm{cm}^{3}$. The absorption coefficient $\mu$ $=0.976 \mathrm{~mm}^{-1}$ and $\mathrm{Z}=4$. Absorption correction was performed by the CRYSTALCLEAR program ${ }^{15}$. The structure was solved by direct methods using the SHELXS-97 program $^{16}$ and refined by full-matrix least-squares techniques on $\mathrm{F}^{2}$ data using SHELXL-97 ${ }^{17}$. The empirical absorption corrections were applied to all intensity data. All the Hydrogen atoms were located by using the geometric method, with $\mathrm{d}(\mathrm{C}-\mathrm{H})=0.95$ $0.98 \AA$ and $\mathrm{U}_{\mathrm{iso}(\mathrm{H})}=1.2 \mathrm{U}_{\mathrm{eq}(\mathrm{C})}$ or $1.5 \mathrm{U}_{\mathrm{eq}(\mathrm{C} \text {-methyl) }}$. The final fullmatrix least squares refinement gave $\mathrm{R}=0.0521, \mathrm{wR}=0.1303$ $\left(\mathrm{W}=1 /\left[\sigma^{2}\left(\mathrm{~F}_{\mathrm{o}}\right)^{2}+(0.0633 \mathrm{P})^{2}+2.5119 \mathrm{P}\right]\right.$, where $\mathrm{P}=\left(\mathrm{F}_{\mathrm{o}}{ }^{2}+\right.$ $\left.\left.2 \mathrm{~F}_{\mathrm{c}}{ }^{2}\right) / 3\right), \mathrm{S}=1.086,(\Delta / \sigma)_{\max }=0.001,(\Delta \rho)_{\max }=0.883$ and $(\Delta \rho)_{\min }$ $=-0.534 \mathrm{e} / \AA^{3}$.

\section{RESULTS AND DISCUSSION}

The single crystal of the title complex (I) was obtained by slow diffusion of $n$-hexane to the dichloromethane solution of the complex, which was crystallized as air-stable red crystals. The elemental analyses, IR and NMR spectra are in good agreement with the formulae proposed by the X-ray crystallography.

Structure of the Ni(II) complex (I): Crystallographic and refinement parameters are listed in Table-1. The selected bond lengths and angles are given in Tables 2-3. The structure was solved by direct methods. Anisotropic displacement parameters were applied to all nonhydrogen atoms in fullmatrix least-square refinements based on $\mathrm{F}^{2}$. The hydrogen atoms were set in calculated positions with a common fixed isotropic thermal parameter.

The molecular structure of the title complex (I) is shown in Fig. 1. The crystal packing diagram of the title complex (I) is shown in Fig. 2.

As shown in Fig. 1, the Ni(1) atom is coordinated by two phosphorus atoms $(\mathrm{P}(1), \mathrm{P}(2))$ from dppe and two sulfur atoms

\begin{tabular}{|c|c|}
\hline \multicolumn{2}{|c|}{$\begin{array}{c}\text { TABLE-1 } \\
\text { CRYSTAL DATA AND STRUCTURAL } \\
\text { REFINEMENT FOR COMPLEX I } \\
\end{array}$} \\
\hline Items & Values \\
\hline Empirical formula & $\mathrm{C}_{27} \mathrm{H}_{27} \mathrm{NiO}_{2} \mathrm{P}_{3} \mathrm{~S}_{2}$ \\
\hline Formula weight & 599.23 \\
\hline Crystal system & Monoclinic \\
\hline \multicolumn{2}{|l|}{ Unit cell dimensions } \\
\hline $\mathrm{a}\left(\AA,^{\circ}\right)$ & $9.2762(3)$ \\
\hline $\mathrm{b}\left(\AA \AA^{\circ}{ }^{\circ}\right)$ & $17.1214(5)$ \\
\hline $\mathrm{c}\left(\AA,{ }^{\circ}\right)$ & $18.8627(6)$ \\
\hline \multicolumn{2}{|l|}{ Unit cell angles $\left({ }^{\circ}\right)$} \\
\hline$\alpha$ & 90.00 \\
\hline$\beta$ & $96.813(3)$ \\
\hline$\gamma$ & 90.00 \\
\hline Volume $\left(\AA^{3}\right)$ & 2974.66(15) \\
\hline $\mathrm{Z}$ & 4 \\
\hline Temperature (K) & 143(10) \\
\hline Space group & $\mathrm{P} 21 / \mathrm{n}$ \\
\hline Wavelength $(\AA)$ & 0.71073 \\
\hline Calculated density $\left(\mathrm{g} \mathrm{cm}^{-3}\right)$ & 1.338 \\
\hline Absorption coefficient $\mu\left(\mathrm{mm}^{-1}\right)$ & 0.976 \\
\hline $\mathrm{F}(000)$ & 1240 \\
\hline Crystal size $\left(\mathrm{mm}^{3}\right)$ & $0.40 \times 0.36 \times 0.24$ \\
\hline$\theta$ range for data collection $\left({ }^{\circ}\right)$ & $3.25-26.37$ \\
\hline Limiting indices & $\begin{array}{l}-11<=\mathrm{h}<=11,-21<=\mathrm{k}<=18, \\
-23<=1<=22\end{array}$ \\
\hline Reflection collected & 14774 \\
\hline Independent reflection & $6073\left(\mathrm{R}_{\mathrm{int}}=0.0282\right)$ \\
\hline Completeness to $\theta_{\max }(\%)$ & 99.79 \\
\hline Data/restraints/parameters & $6073 / 0 / 317$ \\
\hline Goodness-of-fit on $\mathrm{F}^{2}$ & 1.086 \\
\hline Final $R$ indices $[\mathrm{I}>2 \sigma(\mathrm{I})]$ & $\mathrm{R}_{1}=0.0521, \mathrm{wR}_{2}=0.1303$ \\
\hline $\mathrm{R}$ indices (all data) & $\mathrm{R}_{1}=0.0713, \mathrm{wR}_{2}=0.1425$ \\
\hline Largest diff.e peak and hole $\left(\mathrm{e}^{-3}\right)$ & 0.883 and -0.534 \\
\hline
\end{tabular}

TABLE-2

SELECTED BOND LENGTHS (§) FOR COMPLEX I

\begin{tabular}{cc}
\hline Bond lengths & X-ray crystal \\
\hline $\mathrm{Ni}(1)-\mathrm{S}(1)$ & $2.2192(10)$ \\
$\mathrm{Ni}(1)-\mathrm{S}(2)$ & $2.2147(11)$ \\
$\mathrm{Ni}(1)-\mathrm{P}(1)$ & $2.1500(10)$ \\
$\mathrm{Ni}(1)-\mathrm{P}(2)$ & $2.1756(10)$ \\
$\mathrm{S}(1)-\mathrm{P}(3)$ & $2.0265(16)$ \\
$\mathrm{S}(2)-\mathrm{P}(3)$ & $2.0283(15)$ \\
$\mathrm{O}(1)-\mathrm{P}(3)$ & $1.588(4)$ \\
$\mathrm{O}(2)-\mathrm{P}(3)$ & $1.474(3)$ \\
\hline
\end{tabular}

TABLE-3

SELECTED BOND ANGLES $\left({ }^{\circ}\right)$ FOR COMPLEX I

\begin{tabular}{cc} 
Bond angles & X-ray crystal \\
\hline $\mathrm{S}(2)-\mathrm{Ni}(1)-\mathrm{S}(1)$ & $88.35(4)$ \\
$\mathrm{P}(1)-\mathrm{Ni}(1)-\mathrm{S}(1)$ & $88.14(4)$ \\
$\mathrm{P}(1)-\mathrm{Ni}(1)-\mathrm{S}(2)$ & $176.47(4)$ \\
$\mathrm{P}(1)-\mathrm{Ni}(1)-\mathrm{P}(2)$ & $88.18(4)$ \\
$\mathrm{P}(2)-\mathrm{Ni}(1)-\mathrm{S}(1)$ & $173.98(4)$ \\
$\mathrm{P}(2)-\mathrm{Ni}(1)-\mathrm{S}(2)$ & $95.35(4)$ \\
$\mathrm{P}(3)-\mathrm{S}(1)-\mathrm{Ni}(1)$ & $85.87(5)$ \\
$\mathrm{P}(3)-\mathrm{S}(2)-\mathrm{Ni}(1)$ & $85.95(5)$ \\
$\mathrm{S}(1)-\mathrm{P}(3)-\mathrm{S}(2)$ & $99.28(6)$ \\
$\mathrm{O}(1)-\mathrm{P}(3)-\mathrm{S}(1)$ & $109.42(14)$ \\
\hline
\end{tabular}




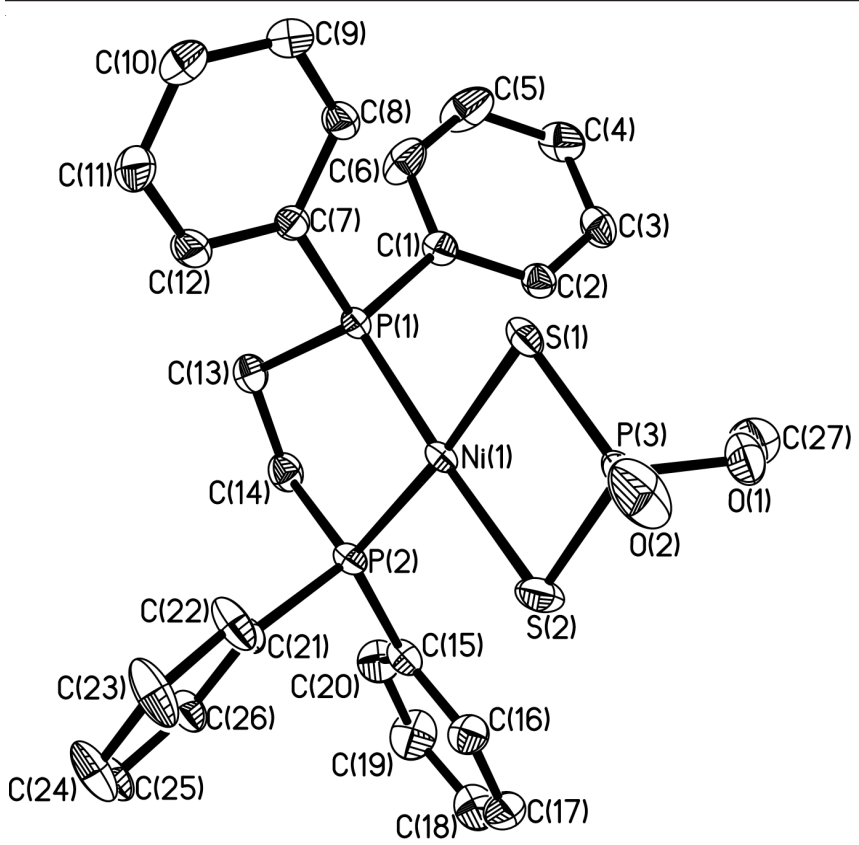

Fig. 1. Molecular structure of complex I with $30 \%$ probability thermal ellipsoids

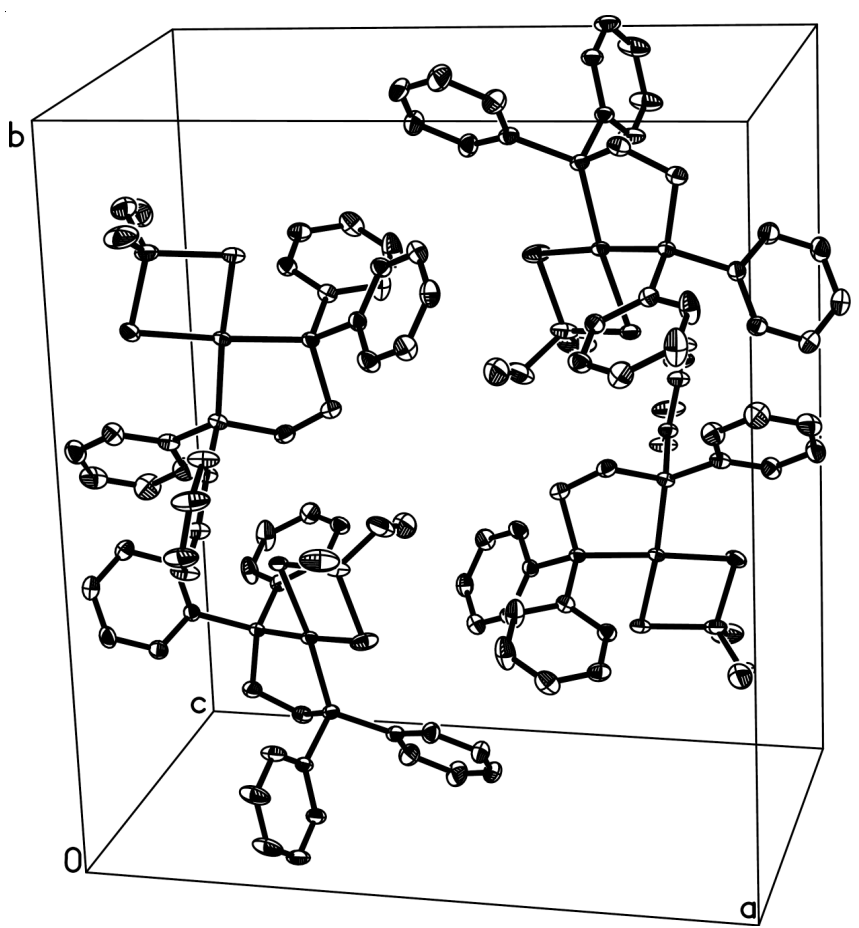

Fig. 2. Crystal packing diagram of complex $\mathbf{I}$

(S(1), S(2)) from one O-methyldithiophosphato. The geometry at the Ni centre in the title complex $(\mathbf{I})$ is square-planar with the $\mathrm{NiP}_{2} \mathrm{~S}_{2}$ chromophore. The $\mathrm{Ni}(1)-\mathrm{P}(1)$ bond length (2.1500(10) $\AA$ ), Ni(1)-P(2) bond length (2.1756(10) $\AA$ ), Ni(1)$\mathrm{S}(1)$ bond length $(2.2192(10) \AA$ ) and $\mathrm{Ni}(1)-\mathrm{S}(2)$ bond length $(2.2147(10) \AA)$ are almost the same length as the corresponding bonds of the complex $\left[\mathrm{Ni}\left(\mathrm{S}_{2} \mathrm{P}\{\mathrm{O}\} \mathrm{OCH}_{2} \mathrm{CH}_{3}\right)(\mathrm{dppe})\right]$ (Ni(1)-P(3) bond length (2.1414(6) $\AA$ ), Ni(1)-P(2) bond length

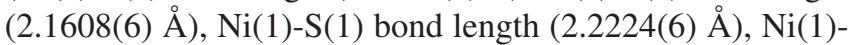
$\mathrm{S}(2)$ bond length $(2.2124(6) \AA)^{18}$, which proves that phosphorus and sulfur atoms coordinate to nickel atom. The $\mathrm{O}(2)=\mathrm{P}(3)$ double bond length $(1.474(3) \AA)$ is shorter than the O(1)-P(3) single bond length $(1.588(4) \AA)$, which is consistent with the results of IR spectra. The sum of the selected bond angles $\mathrm{P}(2)-\mathrm{Ni}(1)-\mathrm{P}(1)\left(88.18(4)^{\circ}\right), \mathrm{P}(1)-\mathrm{Ni}(1)-\mathrm{S}(1)\left(88.14(4)^{\circ}\right), \mathrm{S}(1)-$ $\mathrm{Ni}(1)-\mathrm{S}(2)\left(88.35(4)^{\circ}\right)$ and $\mathrm{P}(2)-\mathrm{Ni}(1)-\mathrm{S}(2)\left(95.35(4)^{\circ}\right)$ is $360.02^{\circ}$, which indicated that the coordination geometry around nickel is distorted from an ideal arrangement. In addition, as shown in Fig. 2, one cell contains four molecule structural units.

TGA analysis for the present $\mathrm{Ni}$ (II) complex (I): To reveal the thermal stabilities of the title complex, TGA measurement has been carried out on a NETZSCH STA 409 $\mathrm{PC} / \mathrm{PG}$ instrument with a flow of dry air at a heating rate of 5 ${ }^{\circ} \mathrm{C} / \mathrm{min}$ from room temperature to $800{ }^{\circ} \mathrm{C}$, shown in Fig. 3 . With the temperature increasing to $460{ }^{\circ} \mathrm{C}$, the complex is completely decomposed.

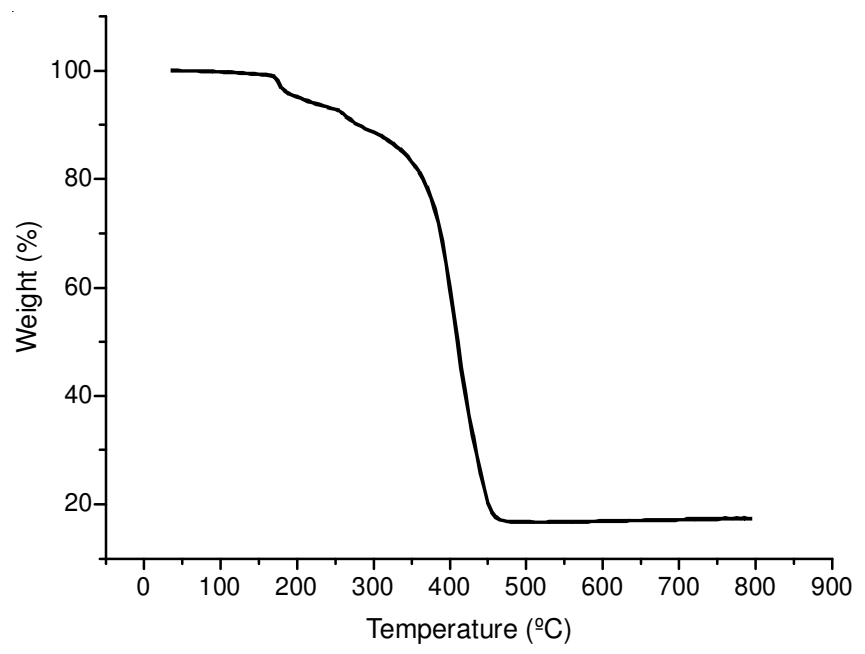

Fig. 3. TG curve for the title complex I

\section{Conclusion}

In summary, O-methyldithiophosphato nickel complex $\left[\mathrm{Ni}\left(\mathrm{S}_{2} \mathrm{P}\{\mathrm{O}\} \mathrm{OCH}_{3}\right)(\right.$ dppe $\left.)\right](\mathbf{I})$ has been synthesized and structurally characterized by elemental analysis, TGA, IR and ${ }^{1} \mathrm{H}$, ${ }^{13} \mathrm{C},{ }^{31} \mathrm{P}$ NMR spectra. Particularly, the molecular structure of the complex (I) was determined by single-crystal X-ray diffraction analysis. Compared to the traditional way to synthesize the O-alkyldithiophosphato nickel complexes with diphosphine ligands ${ }^{18}$, our synthesis route is found to be simple and efficient.

\section{Supplementary data}

CCDC-920344 contains the supplementary crystallographic data for this paper. These data can be obtained free of charge via http://www.ccdc.cam.ac.uk/conts/retrieving.html, or from the Cambridge Crystallographic Data Centre, 12 Union Road Cambridge CB2 1EZ, UK (Fax: +44-1223-336033; or E-mail: deposit@ccdc.cam.ac.uk).

\section{ACKNOWLEDGEMENTS}

The authors are grateful to Science \& Technology Department of Sichuan Province (2012JY0115, 2011JY0052, 2010GZ0130), Sichuan University of Science \& Engineering (2011RC06, 2012PY04, 2012PY14) for financial support. 


\section{REFERENCES}

1. S. Saito, M. Sakai and N. Miyaura, Tetrahedron Lett., 37, 2993 (1996).

2. S. Saito, S. Oh-tani and N. Miyaura, J. Org. Chem., 62, 8024 (1997).

3. V. Percec, J.Y. Bae and D.H. Hill, J. Org. Chem., 60, 1060 (1995).

4. M. Ueda, S. Saito, S. Oh-tani and N. Miyaura, Tetrahedron, 54, 13079 (1998).

5. A. Sofia, E. Karlström, K. Itami and J.E. Bäckvall, J. Org. Chem., 64 1745 (1999).

6. W. Gao, K. Li and X.-L. Wang, Asian J. Chem., 25, 7876 (2013).

7. L.-L. Duan, M. Wang, P. Li, N. Wang, F.-J. Wang and L.-C. Sun, Inorg. Chim. Acta, 362, 372 (2009)

8. J.-F. Jiang, M. Maruani, J. Solaimanzadeh, W.-F. Lo, S.A. Koch and M. Millar, Inorg. Chem., 48, 6359 (2009).

9. A.A. Lozano, M.D. Santana, G. Garcia, J.E. Barclay, S.C. Davies and D.J. Evans, Z. Anorg. Allg. Chem., 631, 2062 (2005).
10. W.H. Watson, A. Nagl, M.J. Don and M.J. Richmond, J. Chem. Crystallogr., 29, 871 (1999).

11. M. Schmidt and G.G. Hoffmann, Chem. Ber., 112, 2190 (1979).

12. M. Schmidt and G.G. Hoffmann, J. Organomet. Chem., 124, C5 (1977).

13. W.-F. Zhu, A.C. Marr, Q. Wang, F. Neese, D.J.E. Spencer, A.J. Blake, P.A. Cooke, C. Wilson and M. Schröder, Proc. Natl. Acad. Sci. USA, 102, 102 (2005).

14. J.A.S. Bomfim, F.P. de Souza, C.A.L. Filgueiras, A.G. de Sousa and M.T.P. Gambardella, Polyhedron, 22, 1567 (2003).

15. Crystal Clear and Crystal Structure, Rigaku and Rigaku Americas, 9009 New Trails Dr. The Woodlands TX 77381 USA.

16. G.M. Sheldrick, SHELXS97, A Program for Crystal Structure Solution, University of Göttingen, Germany (1997).

17. G.M. Sheldrick, SHELXL97, A Program for Crystal Structure Solution, University of Göttingen, Germany (1997).

18. L. Szucová, Z. Trávnícek and J. Marek, Polyhedron, 22, 1341 (2003). 